\title{
A COVID-19-betegek kórházon belüli újraélesztésének speciális szempontjai
}

\author{
László István dr. - Molnár Csilla dr. \\ Koszta György dr. - Végh Tamás dr. - Fábián Ákos dr. \\ Berhés Mariann dr. - Juhász Marianna dr. - Fülesdi Béla dr.
}

Debreceni Egyetem, Általános Orvostudományi Kar, Aneszteziológiai és Intenzív terápiás Tanszék és Klinika, Debrecen

\begin{abstract}
A koronavírus-pandémia számos kihívással szembesíti az egészségügyi ellátószemélyzetet. A vírus cseppfertőzéssel terjed, és magas a virulenciája, ezért minden olyan beavatkozás, mely légúti aeroszolképződéssel jár, potenciálisan veszélyezteti az ellátásban részt vevők egészségét. A koronavírus-fertőzés mortalitása akár 10\% feletti lehet, ezért a COVID-19-betegek körében gyakori a reanimáció. A reanimáció során fokozott a légúti aeroszolképződés valószínűsége, így magas az ellátószemélyzet fertőződésének a veszélye. Cikkünk célja, hogy gyakorlatorientált áttekintést adjon a koronavírussal fertőzött betegek újraélesztésének specialitásairól.
\end{abstract}

Orv Hetil. 2020; 161(17): 710-712.

Kulcsszavak: keringés- és légzésleállás, újraélesztés, koronavírus, COVID-19

\section{Intrahospital resuscitation of COVID-19 patients}

\begin{abstract}
The coronavirus pandemic is a serious challenge for healthcare workers worldwide. The virus is spread through the air by droplets of moisture when people cough or sneeze and it has a very high virulence. Procedures generating airway aerosols are dangerous for every participant of patient care. Mortality of COVID-19 is above $10 \%$, thus cardiopulmonary resuscitation is an often needed intervention in this patient group. Resuscitation is an aerosol-generating process and thus carries the risk of contamination. The goal of this article is to give a practice-based overview of the specialities of cardiopulmonary resuscitation in coronavirus-infected patients.
\end{abstract}

Keywords: cardiopulmonary arrest, cardiopulmonary resuscitation, coronavirus, COVID-19

László I, Molnár Cs, Koszta Gy, Végh T, Fábián Á, Berhés M, Juhász M, Fülesdi B. [Intrahospital resuscitation of COVID-19 patients]. Orv Hetil. 2020. 161(17): 710-712.

(Beérkezett: 2020. március 27.; elfogadva: 2020. március 30.)

\begin{abstract}
Rövidítések
$4 \mathrm{H} / 4 \mathrm{~T}=$ a keringés- és légzésleállás potenciálisan reverzibilis okai; ASY = asystole; BLS = (basic life support) alapszintű újraélesztés; CAVE = Figyelj!/Vigyázz!; COVID-19 = (coronavirus disease 2019) koronavírus-betegség 2019; CPR = (cardiopulmonary resuscitation) cardiopulmonalis újraélesztés; $\mathrm{DC}=$ (direct current) egyenáram; DNR $=($ do not resuscitate $)$ nem újraélesztendő; $\mathrm{EKG}=$ elektrokardiográfia; $\mathrm{ETT}$ = endotrachealis tubus; FFP2 = (filtering facepiece 2$)$ részecskeszürő félálarc- $2 ; \mathrm{O}_{2}=$ oxigén (molekula); $\mathrm{SGA}=$ (supraglottic airway) gége feletti pozíciójú légúti eszköz; $\mathrm{VF}=$ (ventricular fibrillation) kamrafibrilláció; VT = (ventricular tachycardia) kamrai tachycardia
\end{abstract}

Cikkünk megírásának időpontjáig (2020. 03. 27.) világszerte több mint 580000 COVID-beteget diagnosztizáltak, ezek közül majdnem 27000 meghalt, és aktuálisan is 22000 beteg volt súlyos állapotban (intenzív osztályon, lélegeztetve). Általánosan elmondható, hogy a súlyos állapotú (és elhunyt) betegek idősebbek (voltak), emellett több súlyos társbetegséggel rendelkeznek (rendelkeztek). Az összmortalitás 4,6\% (ez bizonyos országokban a $10 \%$-ot is meghaladja), de a kínai tapasztalatok alapján a súlyos állapotú betegek körében a mortalitás a $60 \%$-ot, a gépi lélegeztetett betegek esetében a $80 \%$-ot is meghaladhatja. Mindezekből adódik, hogy a 
COVID-betegek körében gyakrabban van szükség reanimációra, mely azonban ritkán jár eredménnyel [1].

A vírus cseppfertőzéssel terjed, és magas a virulenciája, ezért minden olyan beavatkozás, mely légúti aeroszolképződéssel jár, potenciálisan veszélyezteti az ellátásban részt vevők egészségét. A reanimáció tipikusan olyan beavatkozás, melynek során nagy a veszélye a cseppfertőzésnek, mert a légúti aeroszolképződés fokozott, emellett az ellátószemélyzetnek nem nagyon van ideje teljes értékű személyi védőfelszerelés felvételére (hacsak nem eleve be van öltözve). A fentiek alapján fennáll annak a veszélye, hogy a reanimáció alatt az ellátók fertőződnek, majd megbetegednek, aminek tragikus következményei lehetnek.

A fentiek miatt a COVID-19-betegek újraélesztése során gyakran kell személyre szabott, egyéni döntéseket hoznunk, melyek során a CPR szakmai irányelvei mellett az infekciókontroll szabályait is be kell tartanunk (1. ábra).

A COVID-19-betegek újraélesztése során az alábbi speciális szempontokat érdemes figyelembe venni, az általános irányelveken túl [2-5]:

- Hangsúlyozottan fontos a 'pre-arrest' állapotok minél előbbi azonosítása és ellátása, a keringés- és légzésleállás megelőzése céljából.
- A védőruha nélküli („unprotected”) CPR kerülése az ellátószemélyzet fertőződésének megelőzése elsődleges fontosságú!

- A védőruházat azonnali elérhetősége és használatának (fel- és levételének) készségszintű ismerete alapvető jelentőségú.

- A minimális védőruházat a CPR elkezdéséhez: FFP2maszk, arcvédő pajzs vagy szemüveg, vízlepergető köpeny, kesztyú (lehetóleg 2 pár).

- A CPR-ben csak a minimálisan szükséges személyzet vegyen részt (mechanikus mellkaskompressziós eszköz nélkül 3, annak használatával 2 fö).

- A CPR során csak a minimálisan szükséges eszközparkot használjuk, az egyszer használatos eszközök előnyben részesítésével.

- Az életjelek keresésekor tartózkodjunk a légzés hármas érzékelésétől („lásd-halld-érezd”), mivel az a beteg és az ellátó arcának közeli elhelyezkedése miatt fokozza a fertőzés átvitelének valószínűségét; a légzőmozgásokat relatíve biztonságos távolságból próbáljuk érzékelni (látni).

- Az előzőek tükrében a nagyérpulzus vizsgálata fontos, de ne vesztegessünk túl sok időt (>10 s) a keresésével; ha bizonytalanok vagyunk, vegyük úgy, hogy nincs pulzus.
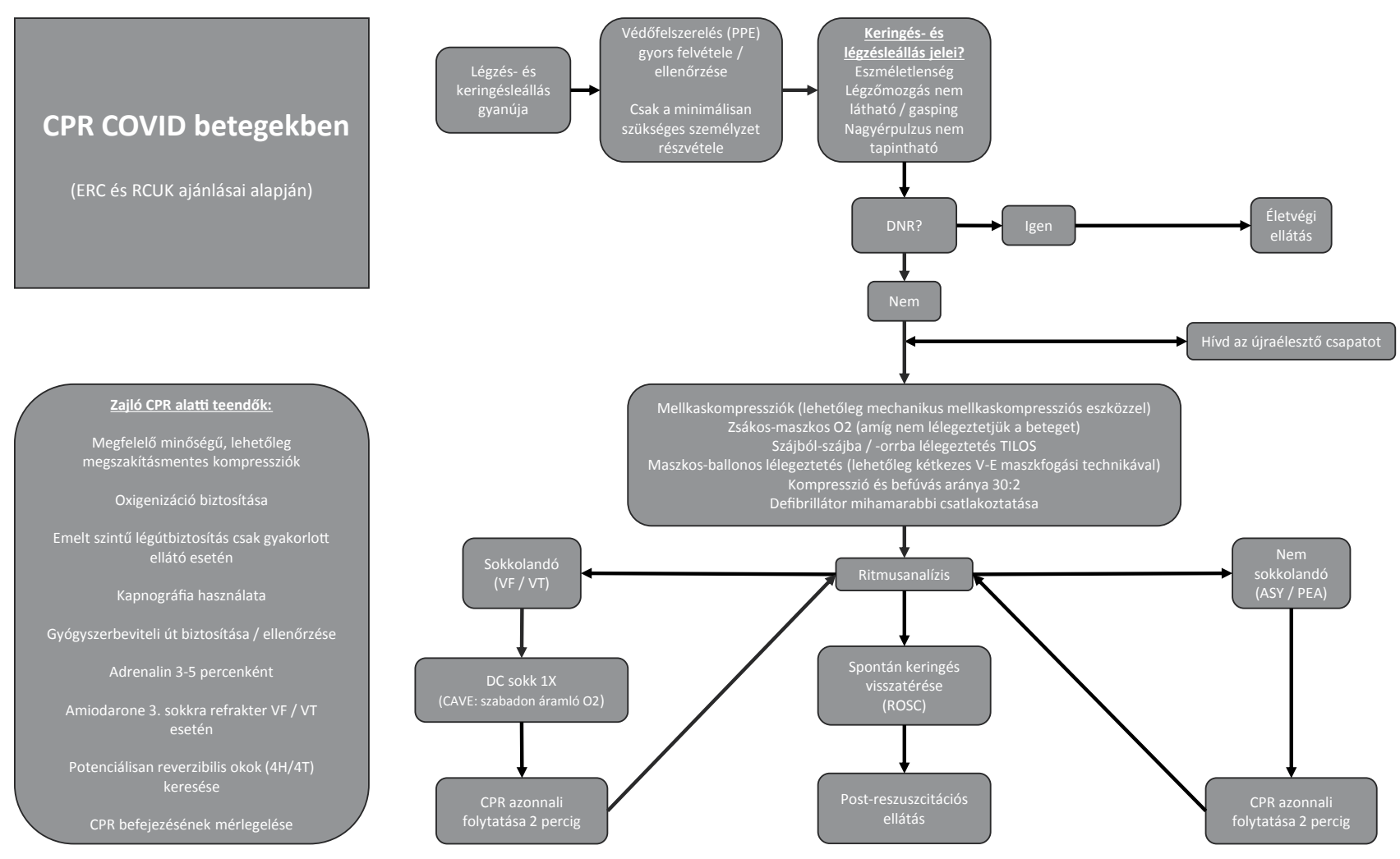

1. ábra

A COVID cardiopulmonalis resuscitatio folyamata

4H $/ 4 \mathrm{~T}$ = a keringés- és légzésleállás potenciálisan reverzibilis okai; ASY = asystole; CAVE = Figyelj!/Vigyázz!; COVID = koronavírus-betegség; CPR = cardiopulmonalis újraélesztés; $\mathrm{DC}$ = egyenáram; DNR = nem újraélesztendő; ERC = Európai Újraélesztési Társaság; PEA = pulzus nélküli elektromos aktivitás; PPE = személyi védőfelszerelés; RCUK = Újraélesztési Társaság (Egyesült Királyság); VF/VT = kamrafibrilláció/kamrai tachycardia 
- BLS során csak megszakítás nélküli mellkaskompreszsziókat végezzünk, kerüljük a szájból szájba lélegeztetést.

- Amennyiben elérhető, és használatában járatosak vagyunk, használjunk mechanikus mellkaskompressziós eszközt (1 segélynyújtót helyettesít).

- Amennyiben van a betegen $\mathrm{O}_{2}$-maszk, azt hagyjuk fenn, ha nincs, helyezzünk fel egyet (apnoés oxigenizáció és a CPR alatt képződő aeroszol elleni protekció céljából).

- A maszkos-ballonos lélegeztetést kétkezes V-E maszkfogási technikával végezzük (mivel ez biztosítja a legjobb fokú tömítést a maszkfogási módszerek közül), illetve használjunk oro- és nasopharyngealis tubusokat a légutak átjárhatóságának fenntartására.

- SGA és ETT behelyezését csak abban járatos személy végezheti.

- ETT és (jól tömítő) SGA hiányában fordítsunk különös figyelmet a szabadon áramló $\mathrm{O}_{2}$ okozta veszélyekre DC-sokk leadása során.

- A keringés- és légzésleállás hátterében a leggyakrabban a hypoxia áll, de más okokat is keressünk (CAVE: $4 \mathrm{H} / 4 \mathrm{~T})$.

- A DNR- (do not resuscitate) elvek érvényesítése, illetve a CPR korai felfüggesztése megfontolandó az alábbi esetekben:

- ismeretlen ideje fennálló légzés- és keringésleállás ( „unwitnessed arrest”),

- ASY az iniciális EKG-n,

- sokkrefrakter VF/VT,

• rövid időn belül ismétlődő keringésleállás („,recurrent arrest"),

- súlyos, előrehaladott, az orvostudomány jelenlegi állása szerint inkurábilis alapbetegség („end-stage” állapot).

Összefoglalásként elmondható, hogy a COVID-19-betegek körében gyakori az újraélesztés iránti igény, mely azonban ritkán sikeres, emellett az ellátószemélyzet cseppfertőzésének fokozott veszélyét hordozza magá- ban. Ezért kiemelten fontos, hogy a COVID-19-betegek újraélesztése során a klinikai helyzetre szabott döntéseket hozzunk, figyelembe véve az újraélesztés általános elveit és az infekciókontroll szabályait is.

Anyagi támogatás: A közlemény megírása anyagi támogatásban nem részesült.

Szerzôi munkamegosztás: L. I.: A kézirat elkészítése. M. Cs., K. Gy., V. T., F. Á., B. M., J. M.: A közlemény szerkesztése. F. B.: A kézirat jóváhagyása. A cikk végleges változatát valamennyi szerző elolvasta és jóváhagyta.

Érdekeltségek: A szerzőknek nincsenek érdekeltségeik.

\section{Irodalom}

[1] Worldometer. COVID-19 Coronavirus Pandemic. Last update: March 27, 2020. Available from: https://www.worldometers. info/coronavirus/ [accessed: March 25, 2020].

[2] Resuscitation Council (UK). Guidance for the resuscitation of COVID-19 patients in hospital. Published online: Mar 24, 2020. Available from: https://www.resus.org.uk/media/statements/ resuscitation-council-uk-statements-on-covid-19-coronaviruscpr-and-resuscitation/covid-healthcare/ [accessed: March 27, 2020].

[3] Brooks M. AHA guidance for CPR, emergency CV care amid COVID-19. Medscape. Published online: March 23, 2020. Available from: https://www.medscape.com/viewarticle/ 927389 [accessed: March 27, 2020].

[4] Morgenstern J. COVID resuscitation principles. First10EM. Published online: Mar 25, 2020. Available from: https://first10em.com/covid-resuscitation-principles/ [accessed: March 27, 2020].

[5] European Resuscitation Council. ERC guidelines for resuscitation 2015. Published online: 15 October 2015. Available from: https://ercguidelines.elsevierresource.com/ [accessed: March $27,2020]$.

(László István dr., Debrecen, Nagyerdei krt. 98., 4032 e-mail: lacipityu@gmail.hu)

A cikk a Creative Commons Attribution 4.0 International License (https://creativecommons.org/licenses/by/4.0/) feltételei szerint publikált Open Access közlemény, melynek szellemében a cikk bármilyen médiumban szabadon felhasználható, megosztható és újraközölhető, feltéve, hogy az eredeti szerző és a közlés helye, illetve a CC License linkje és az esetlegesen végrehajtott módosítások feltüntetésre kerülnek. (SID_1) 